\title{
BUDIDAYA KEPITING SOKA DENGAN METODA SANGKAR MASSAL
}

\author{
Iman Suswanto \\ Fakultas Pertanian, Universitas Tanjungpura \\ email : hayoountan@gmail.com \\ Achmad Mulyadi Sirodjul Munir \\ Fakultas Pertanian Universitas Tanjungpura \\ email: achmadm@yahoo.com
}

\begin{abstract}
ABSTRAK
Mangrove forest stores enormous economic potential. Economic activity in the mangrove forest village Dabong was catching mangrove clams, fish, shrimp and mud crab. Cultivation of soft-shelled crabs can be done with simple methods such as single cage and mass cage combained moulting pool to facilitate moulting monitor the change of the crab skin. Advantages of moulting pool are ease moulting time monitoring and crab moulting secure against attack other animals.Cultivation of soft-shelled crabs need to be developed extensively for broad economic benefits for the sailor. The results indicate that the development of aquaculture activities shelled crabs using mass cage and moulting pool provide greater benefits. Labor productivity with the same can be increased up to 4- fold compared to a single cage aquaculture way. Excellence moulting pool caused by intensive monitoring for skin exchange both day and night.
\end{abstract}

Key words: mangrove, soft shelling crab, and moulting pool

\section{PENDAHULUAN}

Desa Dabong termasuk dalam wilayah Kabupaten Kuburaya yang terletak di daerah pesisir barat daya berbatasan dengan Laut Natuna. Sepanjang pesisir daerah tersebut membentang hutan mangrove dengan luas mencapai 60 ribu hektare. Perjalanan melalui Sungai Kubu, salah satu anak Sungai Kapuas, akan dijumpai vegetasi hutan nipah (Nypa fruticans Wurmb) dan hutan mangrove. Hutan nipah berjejer lebih dari $10 \mathrm{~km}$ menutupi sisi kiri dan kanan pinggiran sungai sampai ke muara. Selepas muara sungai akan dijumpai hutan mangrove memanjang seiring garis pantai. Jenis pohon mangrove yang banyak dijumpai berturut-turut Avicennia sp., Sonneratia alba, Rhizophora sp dan Bruguiera sp. Di daerah ini, hutan mangrove terjaga dengan baik sehingga ketinggian pohon mencapai lebih dari $10 \mathrm{~m}$.

Menurut Kanna (2002) dan Kasry (1996), sumber daya hutan mangrove menyimpan potensi ekonomi yang sangat besar. Kegiatan ekonomi di hutan mangrove berupa penangkapan kerang, 
Website : http:// jurnal.untan.ac.id/ index.php/JPLP2KM ISSN : 2620 - 4665 (print)

ISSN : 2620 - 4673 (online)

ikan, udang dan kepiting. Penangkapan udang dan kepiting banyak dilakukan masyarakat sebagai pekerjaan sampingan oleh anak-anak nelayan maupun para nelayan. Khusus penangkapan kepiting, kegiatan diawali dengan pemasangan perangkap, penangkapan/pemanenan dan akhirnya penjualan hasil tangkapan. Keseluruhan aktifitas penangkapan kepiting memerlukan waktu 1-3 hari.

Produktifitas penangkapan kepiting berkaitan dengan pasang surut air laut. Waktu "musim nyorong" atau periode laut pasang, lantai hutan mangrove terendam air laut, sehingga kepiting bergerak ke zone perakaran mangrove untuk melakukan aktifitas mencari makanan atau kawin. Saat lantai hutan bakau terendam air maka nelayan dapat memasang bubu. Sebaliknya, saat "musim kondah" atau periode laut surut menyebabkan lantai hutan bakau muncul kembali. Saat ini, aktifitas kepiting banyak terjadi di laut lepas. Oleh karena itu, saat musim kondah hanya dapat melakukan penangkapan kepiting soka di sepanjang garis pantai. Umumnya lama periode pasang dan surut air laut berturut-turut 10 dan 6 hari, sehingga dalam satu bulan umumnya terjadi 2 kali "musim nyorong" dan sekali "musim kondah".

Selain periode pasang surut, produktifitas hasil tangkapan kepiting juga dipengaruhi oleh pengaruh musim iklim tropis. Dikenal musim angin barat yaitu angin yang datang dari arah Pulau Sumatera, kondisi kurang kondusif bagi pertumbuhan kepiting, terjadi selama Septrember sampai pertengahan Desember. Berikutnya musim angin selatan, kondisi kondusif bagi pertumbuhan kepiting, terjadi selama Januari sampai Agustus. Kombinasi musim dan periode pasang surut air laut berdampak langsung pada penghasilan penangkap kepiting. Hasil tangkapan kepiting masyarakat berkisar $2-8 \mathrm{~kg} /$ orang/hari atau apabila diuangkan pendapatan harian sebesar Rp 50-200 ribu/hari (Dani, 2012)

Habitat kepiting soka adalah daerah hutan mangrove, sehingga budidaya di daerah ini berkembang baik, ketersediaan bibit kepiting dan ikan rucah sebagai pakan melimpah. Selain itu, permintaan kepiting soka yang terus meningkat menjamin harga pasar yang menarik bagi nelayan (Amir, 1994). Umumnya jalur penjualan kepiting dari nelayan ke pengepul, petambak kepiting soka dan petambak pembesaran kepiting. Selanjutnya produksi kepiting dijual ke konsumen di kota Pontianak atau dikirim ke Jakarta.

Berdasarkan uraian di atas, kegiatan pengabdian kepada masyarakat ini bertujuan untuk mengenalkan metoda sangkar massal sebagai alternatif untuk meningkatkan nilai tambah hasil tangkapan kepiting di alam. Nilai tambah hasil penjualan kepiting soka dapat 
meningkatkan kesejaheraan nelayan karena permintaan yang sangat tinggi dan nilai jual lebih tinggi. Selain itu, budidaya kepiting soka akan menjamin kontinuitas produksi untuk pemasaran antar pulau dan ekspor. Secara keseluruhan, perbakan produksi kepiting soka dapat menjamin keberlangsungan usaha di tingkat produksi (on farm) sampai tingkat penjualan pedagang besar.

\section{METODE PELAKSANAAN}

Kegiatan IbM dilakukan dengan metoda survai ke masyarakat nelayan di Desa Dabong, Kecamatan Kubu, Kabupaten Kuburaya. Tim pelaksana kegiatan membandingkan tata laksana budidaya sistem baterai dengan sistem sangkar massal yang dikembangkan oleh Sethuan \& Ikawati (komunikasi pribadi).

Sarana budidaya berupa karamba apung, sangkar massal dan kolam moulting. Ukuaran karamba apung $4 \times 6 \mathrm{~m}^{2}$, yang sangkar massal $1 \times 0.6 \times 1 \mathrm{~m}^{3}$ dan kolam moulting $1 \times 2 \times 1,2 \mathrm{~m}^{3}$ yang disusun bertingkat. Perlengkapan lainnya berupa pompa air, vertikal submerging pump dan berbagai keranjang plastik untuk mempermudah pengangkutan kepiting maupun pakan.

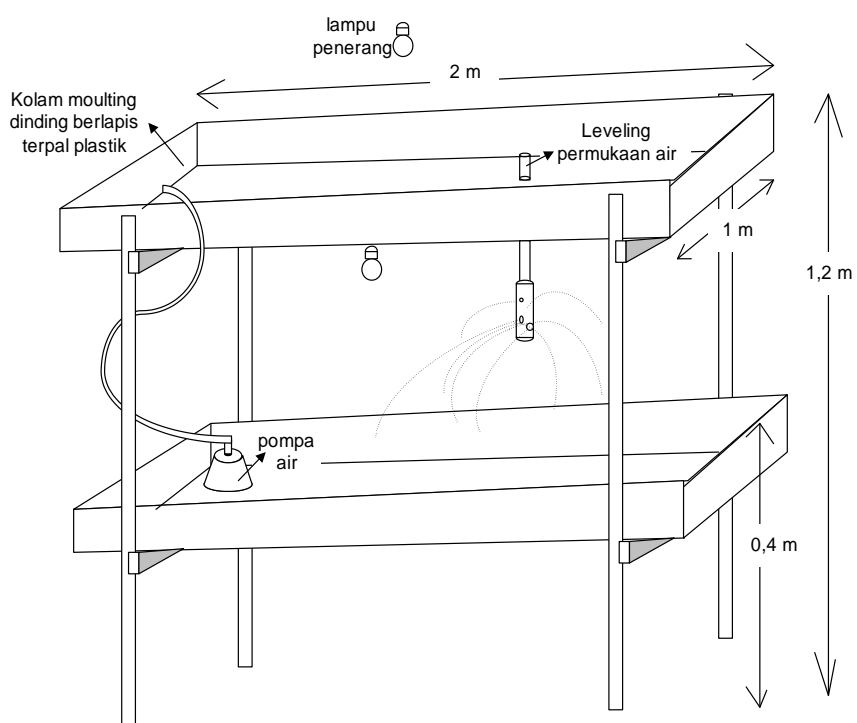




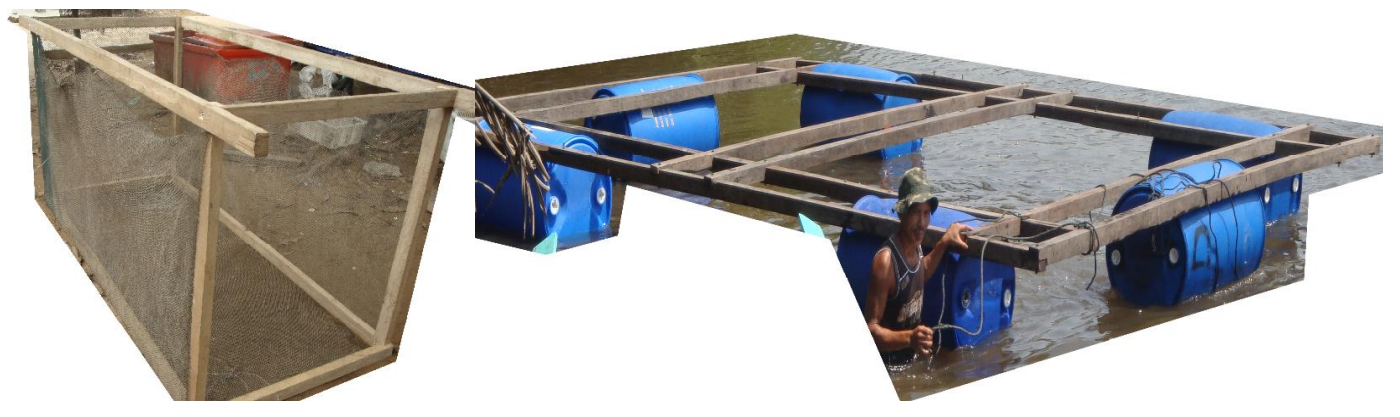

Gambar 1.

Skema kolam moulting, sangkar massal dan karamba apung sebagai sarana produksi kepiting soka

Ukuran kepiting di tingkat nelayan dikenal 3 kelas yaitu kelas A: berat lebih dari 5 ons; kelas B: berat 2,5 - 4,5 ons dan kelas $\mathrm{C}$ : kurang dari 2,5 ons. Kepiting kelas $\mathrm{C}$ inilah yang digunakan sebagai bibit untuk produksi kepiting soka, berisi antara 8-10 ekor/kg.

Pemeliharaan pada sangkar massal merupakan fase pengumpulan energi untuk pemulihan dari perlukaan pemotongan kaki/kastrasi sekaligus untuk pertumbuhan menuju kepiting dewasa. Oleh karena itu, fase ini menentukan kuat atau lemahnya kepiting saat melewati proses ganti kulit. Berdasarkan lamanya penyembuhan maka kepiting dibagi menjadi 3 kelompok yaitu ukuran kecil (maksimal 0,7 ons atau berisi 14-15ekor/kg); ukuran sedang (maksimal 1 ons atau berisi 10 ekor) dan ukuran besar (maksimal 1,5 ons atau berisi 8 ekor $/ \mathrm{kg}$ ). Masing-masing ukuran membutuhkan masa persiapan ganti kulit berturut-turut 14, 17 dan 21 hari perawatan setelah kastrasi. Hal ini penting diketahui karena menentukan waktu pemindahan kepiting dari sangkar massal ke kolam moulting. Ukuran kepiting lebih dari 0,7 ons tidak disarankan untuk dijadikan bibit kepiting soka. Berikut ini langkah-langkah yang ditempuh untuk menghasilkan kepiting soka dengan metoda massal. 


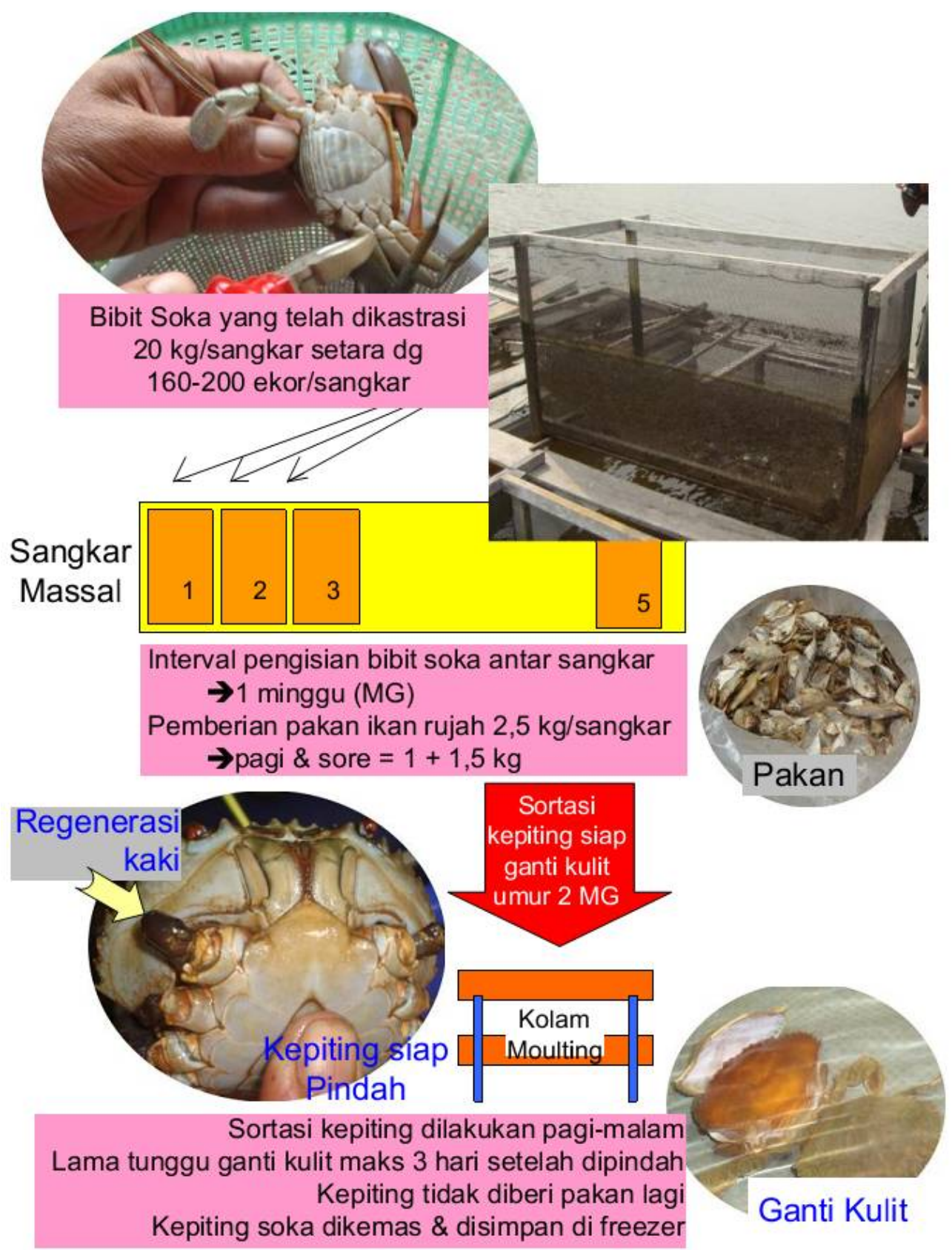

Gambar 2. Teknik budidaya kepiting soka menggunakan sangkar massal disertai kolam moulting (Suswanto \& Mulyadi, 2011)

Pemberian pakan berupa ikan rucah atau ikan kering dilakukan dua kali yaitu pagi dan sore. Jumlah yang diberikan minimal 10\% dari berat total dalam 1 sangkar massal. Dalam kegiatan ini sangkar massal berisi $20 \mathrm{~kg} / \mathrm{sangkar}$, maka jumlah pakan sebanyak 2,5 kg yang diberikan pagi dan sore berturut-turut 1 dan 1,5 kg. Pertimbangan porsi sore lebih banyak karena kepiting lebih 
Website : http:// jurnal.untan.ac.id/ index.php/JPLP2KM ISSN : 2620 - 4665 (print)

ISSN : 2620 - 4673 (online)

banyak beraktifitas pada malam hari. Kecukupan pakan penting diperhatikan karena selain mempercepat pertumbuhan, juga menghindari perkelahian antar kepiting yang dapat berakibat kematian. Meskipun bagian capit kepiting sebagian dipotong, namun tidak menghilangkan sifat kanibal dan suka berkelahi.

Kepiting yang telah ganti kulit segera dipindahkan ke ember berisi air tawar (air hujan) untuk menghindari kulit mengeras kembali. Selanjutnya kepiting ditimbang, dikemas dengan ukuran 3 ons/kemasan dan diawetkan dalam freezer. Menurut Rangka \& Sulaeman (2010) dan Purwanti (2010), pengerasan kulit lunak membutuhkan waktu 4 jam. Pengerasan kulit terjadi akibat absorpsi mineral dan proses enzimatis yang terjadi dalam tubuh kepiting.

\section{HASIL DAN PEMBAHASAN}

Hasil survai menunjukkan bahwa pada awalnya budidaya kepiting soka di Dabong menerapkan sistem baterai atau satu kepiting dalam satu sangkar. Sangkar terbuat dari bahan plastik sederhana (kemasan makanan untuk acara selamatan) yang diikat menjadi paket kandang kemudian diceburkan dalam air sungai. Sebagai pengait sangkar digunakan tali plastik yang diikatkan pada para-para dari kayu Dabong yang dikenal tahan air. Dalam satu paket berisi 12 sangkar dan tutup sangkar terbuat dari jala seperti yang terlihat pada Gambar 3.

Kelebihan teknik budidaya ini relatif mudah, ekonomis dan cukup handal dalam menyesuaikan pasang surutnya air laut. Namun demikian terdapat beberapa kelemahan antara lain sangkar mudah rusak disebabkan oleh konstruksi sangkar kurang kokoh, ribet saat monitoring proses ganti kulit karena harus mengangkat paket sangkar, dan banyak kepiting ganti kulit yang dimangsa binatang air lain dan jumlah kepiting yang mampu diusahakan relatif sedikit (skala kecil). Teknik ini dengan tenaga kerja ayah dan seorang anak hanya mampu mengusahakan kurang lebih 700 kandang. 


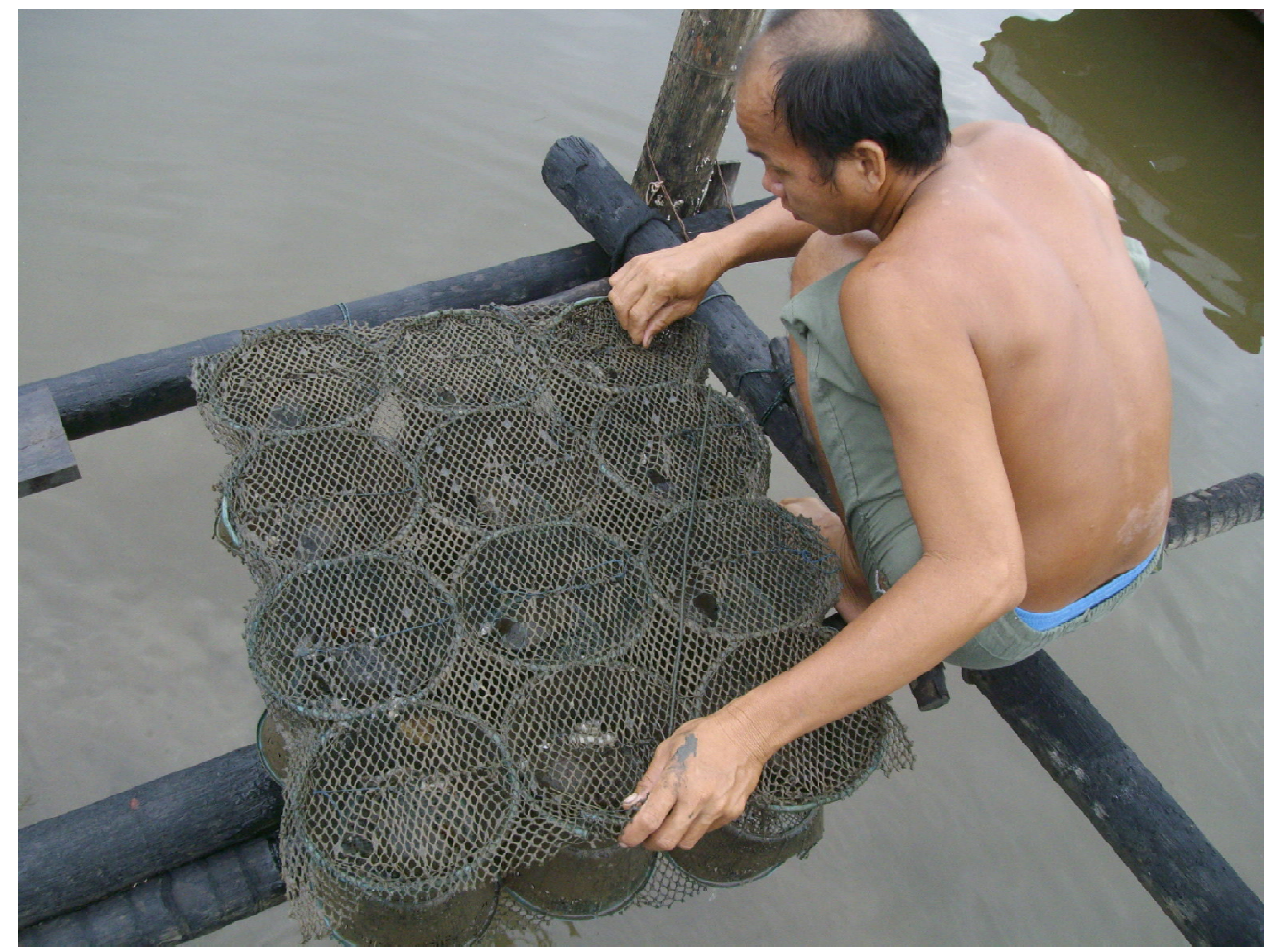

Gambar 3. Budidaya kepiting soka sistim batrey di Desa Dabong, Kalimantan Barat

Belakangan nelayan setempat menerapkan teknik budidaya baru dengan teknik yang ditemukan oleh Sethuan \& Ikawati. Ada 2 perbedaan besar dengan cara lama yaitu saat perawatan bibit kepiting soka dan saat akan ganti kulit seperti yang terlihat pada Gambar 4. Dengan cara ini, tenaga kerja yang sama ternyata dapat menghasilkan kepitng soka 6 kali lipat lebih banyak, yaitu 2-3 kuintal/bulan untuk teknik baru, sementara cara lama hanya 0,5 kuintal/bulan. Kunci keberhasilan metoda Sethuan \& Ikawati adalah kemudahan dalam monitoring ganti kulit. Pada cara ini, monitoring dilakukan setiap saat. Sementara cara lama hanya dilakukan sekali pada pagi pada pagi hari antara pukul 06.00-08.00. Waktu malam hari tidak memungkinkan untuk dilakukan monitoring kepiting soka. 


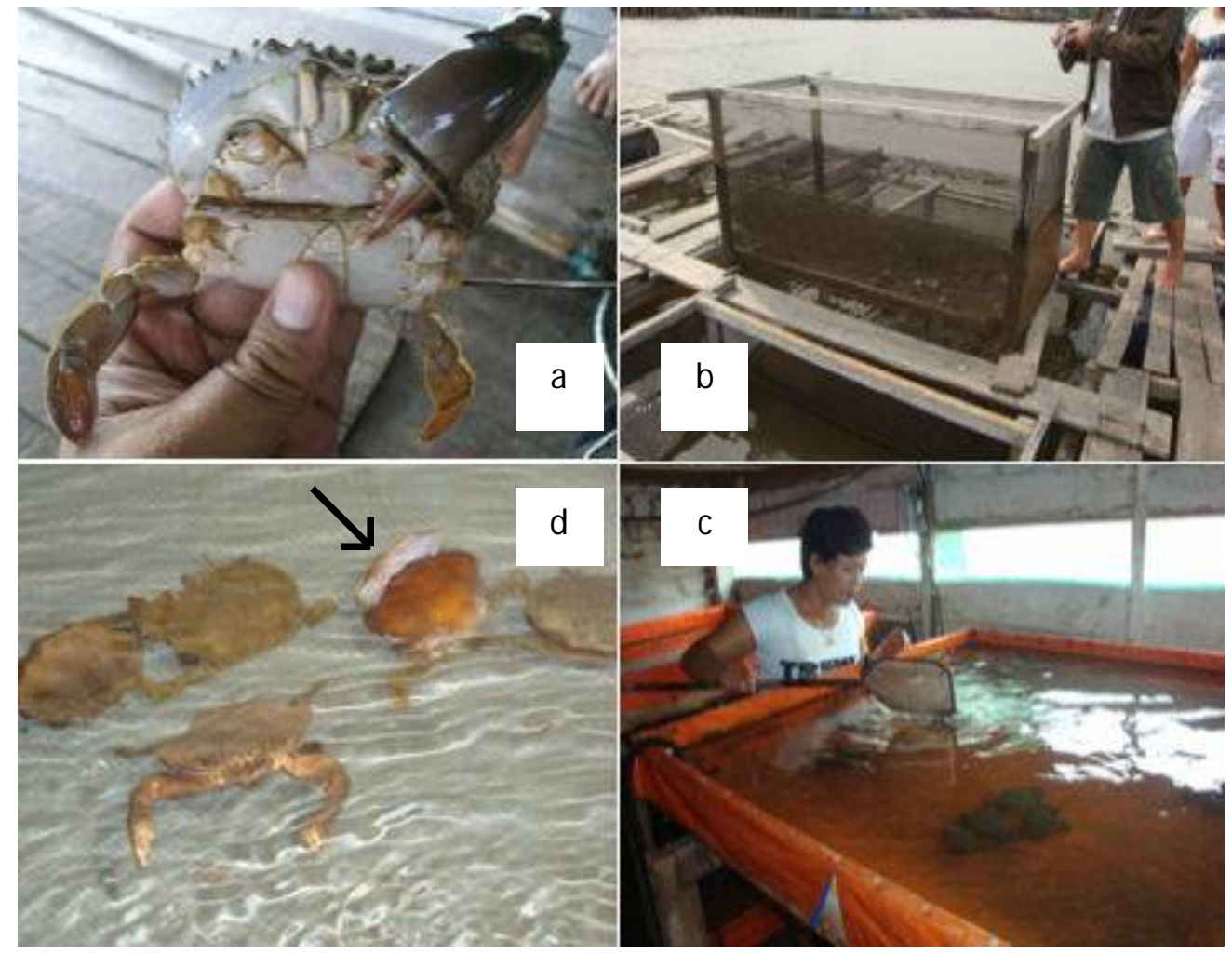

Gambar 4. Teknologi budidaya kepiting soka sistim massal yang dilengkapi dengan kolam moulting. Kastrasi dengan memotong semua kaki dan memotong ujung capit. Kaki belakang dan capit tidak dipoong (a). Sangkar massal berisi kepiting kelas C (b). Monitoring dan kepiting yang sedang ganti kulit (tanda panah) di kolam moulting (c, d).

Hasil pengamatan pada perawatan di kolam moulting menunjukkan cukup berhasil. Kolam moulting adalah tempat perawatan kepiting mencapai proses ganti kulit atau moulting. Saat kepiting dipindah ke kolam tidak lagi mendapat makanan (dipuasakan). Hal ini tidak masalah, karena saat persiapan kepiting akan ganti kulit ditunjukkan dengan perilaku yang tenang atau diam meskipun diusik dan tidak melakukan aktifitas makan. Hal terpenting saat itu adalah pasokan oksigen yang cukup. Oleh karena itu, perlengkapan kolam moulting adalah adanya pompa yang diperlukan untuk memperbaiki aerasi dan pengaturan tinggi permukaan air kurang lebih $5 \mathrm{~cm}$.

Menurut Mossa et al. (1995), kegagalan ganti kulit berupa kematian dapat disebabkan oleh beberapa hal antara lain: perhitungan waktu pemindahan kepiting dari sagkar massal ke kolam moulting yang terlalu awal, kondisi kepiting lemah dan pengatura aerasi yang buruk. Pekerjaan mensortir kepiting yang siap atau belum siap dipindah ke kolam moulting bukanlah perkerjaan 
Website : http:// jurnal.untan.ac.id/ index.php/JPLP2KM ISSN : 2620 - 4665 (print)

ISSN : 2620 - 4673 (online)

mudah, karena melibatkan ribuan kepiting. Kadangkala pemindahan dilakukan serempak berdasarkan nomor sangkar. Akibatnya, banyak kepiting yang seharusnya masih menerima makanan ikut terbawa ke kolam moulting. Dampaknya, selain masa tunggu yang lama, juga kemungkinan akan menyebabkan kematian bagi kepiting lain yang moulting atau kepiting mati kelaparan. Masa yang dipekenankan kepiting tinggal dikolam maksimal 3 hari.

\section{SIMPULAN DAN REKOMENDASI}

\section{SIMPULAN}

Berdasarkan uraian di muka dapat disimpulkan bahwa:

- Budidaya kepiting soka di hutan mangrove memberi keuntungan yang relatif besar;

- Budidaya kepiting soka dengan kolam moulting menghasilkan produktifitas yang lebih tinggi mencapai 2-3 kuintal/bulan;

- Penerapan budidaya kepiting soka menjadi pemacu pemberdayaan masyarakat nelayan.

\section{REKOMENDASI}

Keberhasilan produksi kepiting soka dengan metoda massal dapat ditingkatkan melalui pemberian pakan yang dapat memicu terjadinya ganti kulit sehingga akan mempersingkat keberadaan kepiting di kolam massal maupun kolam moulting. 
Website : http:// jurnal.untan.ac.id/ index.php/JPLP2KM ISSN : 2620 - 4665 (print)

ISSN : 2620 - 4673 (online)

\section{DAFTAR PUSTAKA}

Amir. 1994. Penggemukan dan Peneluran Kepiting Bakau, Techner. Jakarta.

Kanna, I. 2002, Budidaya Kepiting Bakau Pembenihan dan Pembesaran, Yogyakarta, Kanisius.

Kasry, A. 1996. Budidaya Kepiting Bakau dan Biologi Ringkas, Penerbit Bharata. Jakarta.

Mossa, K., I. Aswandy \& A. Kasry. 1995. Kepiting Bakau Scylla serrata dari Perairan Indonesia. LON - LIPI. 18 hal.

Dani, U. 2012. Buku catatan pembelian/penjualan kepiting dan ikan. unpublished

Purwanti, P. 2010. Ecdysis pada Scylla. Osceana 35 (4): 1-10

Rangka, N.A. \& Sulaeman, 2010. Pemacuan pergantian kulit kepiting bakau (Scylla serrata) melalui manipulasi lingkungan untuk menghasilkan kepiting lunak. Proc. Forum Inovasi Teknoligi Akuakultur. 